\title{
The Oedipal Detective and the Riddling Metropolis: New Visions of Urban Catharsis in BBC's Sherlock
}

\author{
Dana Vasiliu \\ University of Bucharest, Romania
}

\begin{abstract}
The present paper is the result of interdisciplinary research (urban sociology and film adaptation studies) and critical reflection on identity construction and new urban setting. Building of Durkheim's concept of anomie and Goffman's concept of blasé outlook, the paper attempts to demonstrate that the $21^{\text {st }}$ century metropolis posits similar challenges to identity as ever. Even though the new millennial Sherlock is confronted with the encodings of the digitized metropolis, the seemingly 'computerized detective' functions on the same rules of human agency and enters the same paradigm of hubristic behaviour as any classical hero. Sherlock's and Watson's cathartic release of emotional blockages compensate for the anomic, alienating effect that the metropolis has on the modern urbanite. Moreover, despite the differences in space or social and communication practices, the famous detective pair has not ceased to solve mystery and crime puzzles. They have adapted to the new reality. As this paper postulates, millennial Sherlock is still an exceptional reasoner who has calibrated his most powerful tool of deduction, his own brain, to the rapid and volatile transformations of the $21^{\text {st }}$ century informational city.
\end{abstract}

Keywords: anomie, alienation, cyberspace, New metropolis, non-places

\section{Introduction}

In 1885, when Sir Arthur Conan Doyle first jotted down 'Sherrinford Holmes and Ormond Sacker' revealing thus the-not-yet fully fledged names of his consulting detective and companion, he had no idea that he was carving out a long-term career as a detective fiction writer. Two years later, when Sherlock Holmes and Dr. John Watson made their first appearance in Beeton's Christmas Annual, he little imagined that, just like the blue-haired fairy in Carlo Collodi's story, he was breathing immortal life into his characters. Another three years and the couple made it to the screen. Since then, "no other fiction character has been the subject of so many interpretations (with the possible exceptions of Dracula and Frankenstein)" (Werner, 2014, p. 7). To date there have been hundreds of film adaptations, to say nothing of the scores of radio programmes, theatre plays and documentaries, which resulted in an official 2012 Guinness World Record for the most portrayed human literary character on film and television. 
And yet, "there are three principal characters in the Holmes and Watson stories: the great detective, the good doctor and the ever-present metropolis." (Cannadine as cited in Werner, 2014, p. 15) Introduced as "the great cesspool into which all the loungers and idlers of the Empire are irresistibly drained" (A Study in Scarlet) nineteenth-century London has been pinned a Dionysian identity tag bespeaking cosmopolitan promiscuity and pseudo-Bohemian tastes. Luckily enough, two quasi-Oedipal characters, Sherlock Holmes and Dr. Watson, have made their quarters at the very 'heart' of the mother-city. 221B Baker Street has ever since become the centre of Apollonian catharsis where fastidious observation, unbiased analytical judgement, inductive/abductive reasoning and logical synthesis are employed to bring atonement to a hubristic decadent world.

Paradoxically, despite the time-lapse which has presumably changed the 'mores' of the Victorian metropolis and blown away its mystifying secretive 'fog', in post-industrial skyscrapered London crimes are still solved "in the reassuring rooms of 221B Baker Street." (Hardy as cited in Werner, 2014, p. 150). For just as the late Victorian urbanite living in a turbulent world made more and more permeable by a waning imperial pathos was in constant need of reassurance, so does the $21^{\text {st }}$ century Londoner confront with the prospect of racist violence and extremist terrorism. But transplanting a hero equipped only with his power of deduction and an array of outdated information tools in a highly digitized metropolis is not a solution per se. Every hero needs an updating now and then, no matter the hero's portfolio. And it is precisely this that the BBC version of Sherlock Holmes $(2010$ - 2017) offers: an exceptionally savvy sleuth, a high functioning brain, a texting virtuoso who brings legibility and meaning to the otherwise Delphic utterances of the riddling metropolis.

\section{The Challenges of the New Metropolis}

\subsection{The anomic condition of the metropolitan urbanite}

The hermeneutical challenge that the New Metropolis posits is not actually new. In an age of crime dominated by the elusive figure of Jack the Ripper, late Victorian London was teemed with riddles which required an exceptional interpretative effort to reason them through. Such a recondite enterprise would call for a gifted character able to unravel the mysteries that the city produced. A talented hero capable of mastering the fog, "the wilderness of alleys and thoroughfares" (Hekhuis, 2008, p. 39) of the labyrinthine city and the artful intricacy of the criminal mind:

Within that literary genre, the ratifying figure of the detective served to assure that the ominous modern metropolis could be brought to light, understood and controlled. One of the reasons Holmes was so veneered among a Victorian readership was his ability to restore their faith in rationality in a time when ideological terror of mass urbanisation was rife. Holmes's almost preternatural skills of deduction allowed him to read the city and know it intimately. (Lee, 2014, p. 182)

In The Red-Headed League (1892), a self-assured composed Holmes tells Watson: "It is a hobby of mine to have an exact knowledge of London". And he is not being boastful when he claims that he knows the city by 'heart'. His unmatchable expertise is endorsed by John Watson after the detective's almost-fatal encounter with Professor Moriarty when the good doctor marvels at Holmes's "knowledge of the byways of London" and calls it 'extraordinary'. One hundred and eleven years after the first publication of The Adventures of the Empty House (1903) another 'resurrected' Sherlock would enthusiastically ask his 


\section{iorhs}

\section{4th International Conference On Research In}

HUMANITIES \& SOCIAL SCIENCES

brother, Mycroft: "Just put me back in London. I need to get to know the place again, breathe it in - feel every quiver of its beating heart." (The Empty Hearse, Series 3, Episode 1) Substitute Conan Doyle for Mycroft and the words change from mild entreaty to ardent supplication made by the hero who has 'survived' the plunge into the Reichenbach Falls to his all-powerful Creator (the Author-God).

Nevertheless, predestined or not, that was definitely not Sherlock's 'final problem'. In other words, be careful what you wish for lest it come true. For Steven Moffat and Mark Gatiss's contemporary take on Conan Doyle's 'creation' plunges Sherlock and John into a tidal metropolis, a space of hubs and flows, to paraphrase Manuel Castells. For the present "information age is ushering in a new urban form, the informational city" (Castells, 1996, p. 429) and together with it a new anomie: the informational anomie of the network society. Mainly a by-product of the third-millennium digitized mega-city, this new form of alienation has been triggered by the hyper-virtualization of reality, be it space or social and communication practices. Paradoxically, the closer we are in media spaces, the more estranged and anomic we become in real life. People no longer share a space, they 'text' it i.e. they transform it into a cyberspace populated by monadic avatars whose sole predictive practice of communication is a hashtag.

For instance, in the first episode of the Sherlock series, borrowing Watson's mobile to text a message is probably Sherlock's most intimate form of bonding. One's mobile has become one's most private accessory. A man's hat has long ceased to be his aura of domestic legibility. In The Empty Hearse Sherlock and Mycroft's competition over analyzing a client's left behind knitted hat reverses the object of analysis into a self-reflexive subject of analysis for it is Mycroft who is under scrutiny not Howard Shilcott, the true owner of the hat. Chapeau, as the French would say.

SHERLOCK: Let's play something different.

MYCROFT (with an exasperated sigh): Why are we playing games?

SHERLOCK: Well, London's terror alert has been raised to Critical. I'm just passing the time. Let's do deductions. (...)

MYCROFT: I find nothing irresistible in the hat of a well-travelled anxious sentimental unfit creature of habit with appalling halitosis.

SHERLOCK: Isolated, too, don't you think?

MYCROFT: Why would he be isolated?

SHERLOCK: "He"?

MYCROFT: Obviously.

SHERLOCK: Why? Size of the hat?

MYCROFT: Don't be silly. Some women have large heads too. (...) No - he's recently had his hair cut. You can see the little hairs adhering to the perspiration stains on the inside.

SHERLOCK: Some women have short hair, too.

MYCROFT: Balance of probability.

SHERLOCK: Not that you've ever spoken to a woman with short hair - or, you know, a woman. (...) But you've missed his isolation. (...)

MYCROFT: ... I'm not lonely, Sherlock. 


\section{SHERLOCK: How would you know?}

In A Study in Pink, another character has to face up the prospect of loneliness and emotional impairment. Having just returned from Afghanistan and unable to adapt to civilian life, former army doctor John Watson drifts into anomic isolation. His nightmarish reliving of scenes from the battlefield, the repetitive intrusive flashbacks of a traumatic memory make him a perfect candidate for PTSD. The space he inhabits, a simple yet tidy functional room, void of any visible personal items or any family memorabilia augments his sense of alienation and loneliness. Slightly aphasic, unable to communicate or bond, self-reflexive and excessively pensive, Watson apparently toys with the idea of suicide. Shattered by the experience of war he seems on the verge of committing 'anomic suicide', to use Durkheim's phraseology (1952). Besides, the alienating heterogeneity of the metropolis adds to his disorientation and altered sense of belonging.

"Nothing happens to me" is what John Watson truly laments for. It is not that he experiences a condition of inadequacy and purposelessness resulting from post-traumatic disorder or the despondency and jadedness of a suicidal man. A red-herring, as any experienced detective fiction reader will definitely know. For Watson, war has proven to be an individual tonic to boost his confidence and independence. As Mycroft will later notice: "You are not haunted by the war, Dr. Watson, you miss it." (A Study in Pink) What Watson needs are new stimuli to help him overcome his anomic condition; and it is precisely this that London and Sherlock offer him: an active escape route from the otherwise blasé indifference of the metropolitan lifestyle.

MYCROFT: "Most people blunder around this city and all they see are streets and shops and cars. When you walk with Sherlock Holmes you see the battlefield."

To paraphrase Erving Goffman, the metropolis fosters the culture of 'inattention' and distancing: we consider what is relevant to us and fail to notice or purposefully overlook the overfamiliar or the non-essential. Caught in the web of kaleidoscopic, fragmented, dense multisensory experiences that the metropolis spins, one can only avoid overloading by applying selective inattention and safeguarding indifference:

A common stance of urban dwellers is thus the blasé outlook, a renunciation of responsiveness (...). Often accompanying this outlook is to be found an attitude of reserve. A reserved attitude acts as a protective shield for the urban dweller behind which candid views and heartfelt sentiments can be preserved from scrutiny. (Longhurst et al., 2013, p. 272)

Undoubtedly, the density and proximity of social interactions the urbanite experiences do not equate with genuine interpersonal engagement nor do they elicit any true emotional responsiveness. "In the modern metropolis, individuals are made to fall back on themselves, roaming like monads through the anonymous crowds," (De Meyer, 1999, p. 68) in "the ceaseless livestream of traffic and strangers, each an atom unto themselves, swirling in a social maelstrom." (Fyfe, 2015, p. 2) To fight the feeling of alienation that the metropolis effects on its dwellers, the urbanite attempts to appropriate space by making it individually significant and valuable. To this end, one creates an itinerary of familiar places, "a city à la carte" (Fishman as cited in De Meyer, 1999, p. 46) a network of post-its attached to an imaginary personalized map signaling out: my place, my school, my office building, etc. All the others are transit areas which either offer passage to familiar destinations (airports, train stations, motorways etc.) or create a temporarily shared area of 'users' (hospitals, department 


\section{iorhs}

\section{4th International Conference On Research In}

HUMANITIES \& SOCIAL SCIENCES

stores, cinemas, wireless networks etc.) The French anthropologist Marc Augé identifies them as 'non-places' from which "we can neither read identities, nor relations, nor history" (Marc Augé as cited in Pleßke, 2014, p. 104):

The non-places of transition and their spatial anonymity are the new home of the passing stranger. Thereby the sense of solitude and anonymity can also lead to the passive joys of identity-loss, and the more active pleasure of role playing. (ibid. p. 105)

Hence, the postmodern geographies of urban non-places serve both as entangled labyrinths where the schizoid character of the anomic urbanite strays and theatrical stages for performing identities. In the first episode of the 2010 BBC series, the serial killer who baffles police with his ingeniously faked suicides assumes the identity of an average inconspicuous London cabbie. This grants him access to almost all metropolitan 'non-places' and the opportunity to choose his victims from among his clients.

His first victim, Sir Jeffrey Patterson, reluctantly takes a cab from the railway station and probably heads for his mistress's apartment or for a secret love nest he shares with his secretary. He would have taken the company car as he always did but for some reason it had gone to Waterloo instead. The second, student James Phillimore, is rushing back home to fetch his umbrella. The malicious rainy London conspires with destiny against him. The third victim, Beth Davenport, politician and junior minister for transport, is celebrating her birthday in a club. As she is in the habit of drinking heavily, her car keys have been taken away by two of her assistants. She slips out of the venue determined to drive up to some secret meeting place which she obviously fails to do. Victim number four, Jennifer Wilson, arrives in London on a train from Cardiff. An adulteress, as Sherlock proves her to be, she was probably heading for an illicit rendezvous with one of her lovers.

All the victims start their ominous journeys from a 'non-place', an area of transit: railway station, club, some residential street and head for a presumably more familiar comforting environment. All of them agonize and eventually die in deserted, empty places where, apparently, they "had no reason to be." (A Study in Pink) And yet it is with good reason that the smartly dressed businessman ends up dead in a large open-plan unfurnished office, stories high above the bustling City. That the student who refuses to share his mate's umbrella expires inside a sports centre overlooking an empty sports court. That the inebriated, 'in the pink' (sic) and most probably corrupted female politician meets her death inside a portacabin on a building site where drug dealers most likely feel 'at home'. And finally, that the highheeled Barbie-styled Jennifer Wilson is killed inside an abandoned residential building in Brixton. All of them are re-located to a reversed space of punitive introspection and some of them are cynically given a vantage point to count their losses. A crime production brilliantly staged and directed by the decadent genius "who mirrors Sherlock's aesthetic appreciation of artful crime" (Harrington as cited in Stein, 2012, p. 82): Holmes's mischievous criminal double, Moriarty.

\subsection{The hubristic character of the computerized detective}

The 'extra-large' size of the urban realm, its complex grid of non-places and overlapping network of equally impersonal digital spaces, the density and heterogeneity of its urban population create "superficial, transitory and segmental social contacts." (Pleßke, 2014, p. 93) 
Metropolitan consciousness is defined by the paradox of proximity (we are close, yet so far away) whereas the digital by the paradox of distancing (we are so far away, yet so close). Both belie reality. This raises the question of how perceptive we are. Apparently, not much. As the original Sherlock Holmes would say: "You see but you do not observe" (A Study in Scarlet) or as today's Sherlock would more emphatically put it: "You do see, you just don't observe!" (The Great Game) For much of the observation spirit involved in every day practices of the urban space consists in scanning the close-by environment for all kinds of practical purposes: finding one's way about, avoiding colliding with others on a busy street etc. What for the ordinary man may seem an instance of sensory overload that drains the energy of the observer and strays him away from his proper pursuits, for Sherlock and John is a day-to-day charging of batteries.

Just like John, Sherlock is an anomic sociopath who practices hyper-stimulation and overarousal to satisfy his need of constantly being engaged. He is domineering, excessive, impulsive, arrogant, a narcissist with a sense of intellectual prowess. In the Crooked Man, Watson describes him as having "that Red Indian composure which made so many regard him as a machine rather than a man." Leaving behind his Amerindian self-possession, twenty-first century Sherlock has become a "computerised detective" (Nicol in Vanacker, 2013, p. 134), a "thinking machine", (Taylor in Porter, 2012, p. 140) an artificial high-speed data processing brain operating "in a technologically-centered world of digital natives" (ibid.): "I am a brain, Watson. The rest of me is a mere appendix", Conan Doyle's Sherlock confesses in The Mazarin Stone unaware that he was describing himself as artificial intelligence avant la letter. Borrowing from this,

The BBC adaptation goes further, and Sherlock's rationalist intelligence sometimes serves to dehumanize him until he is almost at one with the technology he so adeptly manipulates. The BBC production chooses to superimpose typed words upon each clue Sherlock identifies, high lightning the machine-like quality of his thought process. The audience hears robotic sound effects meant to represent Sherlock's computational brain working (...). (Bochman in Porter, 2012, p. 152)

To Donna Haraway (1991) he is a cyborg, "a hybrid of machine and organism" (p. 149) standing for the change from "an organic, industrial society to a polymorphous, information system" (p. 161). Though I do not dispute the validity of any of these readings I find that the robotic or cybernetic identity attributed to Sherlock is debatable. It is true that in The Great Game, Sherlock sees his brain as a 'hard drive' but had he been a "computerised detective" he wouldn't have complained about his limited storage space. There is always disk defragmentation, expanded and extended memory to counteract that. Besides, hard drives never 'rot' but they may 'catch' a virus and get 'infected'.

SHERLOCK: This is my hard drive, and it only makes sense to put things in there that are useful. Really useful. Ordinary people fill their heads with all kinds of rubbish. That makes it hard to get at the stuff that matters.

JOHN: But it's the solar system.

SHERLOCK: Oh, hell! What does that matter? So we go round the Sun! If we went round the Moon, or round and round the garden like a teddy bear, it wouldn't make any difference. All that matters to me is the work! Without that, my brain rots!

There is nothing but organic about Sherlock. He is not a multi-tasking artificial brain; he is simply not an 'ordinary' man functioning on a 'funny little brain' like most people do. The digitized metropolis has not transformed him into some bionic freak, at least not yet. As 


\section{iorhs}

\section{4th International Conference On Research In HUMANITIES \& SOCIAL SCIENCES}

Francesca Coppa observes: "He takes too much physical pleasure - laughing, clapping, gasping, running down stairs" (in Stein, 2012, p. 217) to be robotic. Even the stimulant he takes, nicotine patches, is not some nano-synthetic alkaloid to 'recreate' or increase the performance of an artificial brain. Millennial Sherlock is an exceptional reasoner who has adapted his most powerful tool of deduction: his own brain to the rapid and volatile transformations of the informational city; one who knows that the complex metropolitan geographies of non-places serve as a stage for spectacle which creates a flow of illusion that only the calibrated eye can discern. He is the disenchanter amidst a disturbingly alienating world which "runs on codes and ciphers (...) all computer generated." (The Blind Banker)

While Holmes' scientific knowledge reassured $19^{\text {th }}$ century readers that order could exist in the industrial city, Sherlock's technological expertise eases $21^{\text {st }}$ viewers' anxieties about the digital city and information management. (Anne Kustritz et al., 2014, p. 94)

He above all knows that "the city is a state of mind (...) it is a product of nature, and particularly of human nature." (Park as cited in Pleßke, 2014, p. 90) Even the digital one. To master it, one has to look into and decipher the unfathomable depths of human nature: the most difficult and puzzling task of all, a tantalizing conundrum to solve for human nature is so deceiving:

"Human nature is a strange mixture, Watson." (The Stock Broker's Clerk)

"It is of the first importance," he cried, "not to allow your judgment to be biased by personal qualities. A client is to me a mere unit, a factor in a problem. The emotional qualities are antagonistic to clear reasoning. I assure you that the most winning woman I ever knew was hanged for poisoning three little children for their insurance-money, and the most repellent man of my acquaintance is a philanthropist who has spent nearly a quarter of a million upon the London poor." (The Sign of Four)

Both Conan Doyle's original and the BBC's Sherlock are confronted with the deceptive quality of appearances which transplanted into the floating space of the digitized metropolis become even more treacherous. As Jim Moriarty adeptly proves when he passes off as 'award winning actor' Richard Brook (The Reichenbach Fall), 'breaking into the records', altering one's identity or forging a brand new one is a terrifyingly possible scenario when a viciously malignant mind is at work. And Jim Moriarty is one-of-a-kind criminal mastermind. Apparently in possession of a binary code which renders any security system vulnerable to attack, Moriarty finds no hindrance in setting up a false identity and convincing gullible journalist, Kitty Riley, that he is an actor Sherlock has paid to act as his nemesis. High up on St. Bartholomew's Hospital rooftop, Moriarty confesses that his breaking into the Tower of London was not the result of an ingeniously devised key-code. It all falls back to the duplicity of human nature and its infamous weaknesses:

SHERLOCK: Beats like digits. Every beat is a one; every rest is a zero. Binary code. That's why all the assassins tried to save my life. It was hidden on me; hidden inside my head - a few simple lines of computer code that can break into any system. (...)

MORIARTY: There is no key, doofus! Those digits are meaningless. They're utterly meaningless. You don't really think a couple of lines of computer code are going to crash the world around our ears? (...) Now, how did I break into the bank, to the Tower, to the prison? Daylight robbery. All it takes is some willing participants. I knew you'd fall for it. That's your weakness. You always want everything to be clever.

Sherlock's 'final problem' is admitting that he is no super-human and that his brilliant mind is at peril of becoming blunt if fetishized as a key operated, computerized brain. The 
new millennial world, no matter how digitally encrypted, still works on the 'old' fashioned rules of human agency. This implies taking up complex societal and individual roles and putting up a convincing even if morally staggering performance. Hence, throughout the BBC series, Moriarty is the encoder, the puzzle crafter, the puppet master who goads others into performing violent acts. Conversely, Sherlock is the decoder, a reactive figure who cheerfully concurs to solve the riddles he had been given. At times, Moriarty's God-like pose turns Sherlock hubristic. For example, in the opening scene of the first episode Sherlock is seen repeatedly beating a dead body with a riding crop. Whilst his actions are apparently scientifically motivated, there is no doubt that such an act of molestation would have enraged the ancient gods. There is also the over-weening pride Sherlock takes in identifying himself: the only consulting detective in the world. The very trait that makes the hero noteworthy, his exceptional power of deduction, causes the protagonist's 'fall' as Sherlock fails to properly circumvent Moriarty's maneuvers.

In The Reichenbach Fall, Moriarty lures Sherlock and John into another of his wellconcocted plots: "two children led into the forest by a wicked father" or the "Hansel and Gretel' riddle. Moriarty plays the role of the estranged father, a role he has first embraced in The Great Game: "But the flirting's over, Sherlock. Daddy's had enough now." Switching between roles, Moriarty takes turns acting as a moody Kronos who kills his boredom by scheming against his 'offspring' or as an ill-fated Laius doomed to be killed by his own 'child'. So despite the fairy tale-inspired premise, the ' $\operatorname{grim}(\mathrm{m})$ ' role Moriarty plays brings in new oedipal overtones. For Oedipus has long been considered the 'father' of the detective genre and his story/enquiry although "based on supernatural, pre-rational methods" (Scaggs, 2005, p. 9) has been said to have "all of the central characteristics and formal elements of the detective story, including a mystery surrounding a murder, a closed circle of suspects, and the gradual uncovering of a hidden past." (Scaggs, 2005, p. 11) And, one may add, an identity conundrum that once solved reveals "Oedipus's position as both the criminal and the force of law and authority" (Scaggs, 2005, p. 10); a doubling of functions that Moriarty and Sherlock correspondingly pair: the consulting criminal - the consulting detective. "We were made for each other, Sherlock" (The Great Game) Moriarty cautions his doppelganger.

Plagued by Moriarty's mischievous riddles - just like ancient Thebes in the story of Oedipus was under the terror of the Sphinx - the corrupted metropolis conspires with the perpetrator to trap unsuspecting victims and lead the detective on a trail of 'digital' breadcrumbs to its witchy-urban confinements (see A Study in Pink). In The Blind Banker mysterious symbols are scrawled on the city walls alongside coded graffiti messages. While "people just walk straight past, not knowing, unable to decipher the message" Sherlock like Oedipus is the only one to solve the riddle and unmask the female leader of the Black Lotus. In A Scandal in Belgravia, the place of the Greek Sphinx has been taken by Irene Adler and its sibylline utterances by a mobile phone lock password which the detective eventually cracks: "I am Sher-locked". As the riddle unfolds, a signified-naked Sherlock (alas the 'king' is naked at the very 'heart' of the British nation - Buckingham Palace!) is replaced by a naked-yet-fully-clothed-in-riddles Irene Adler. After outwitting her, a quasi-oedipal Sherlock is left on stage to kill his 'daddy' and lift the plague that has struck the (mother) city. Just like Conan Doyle before them, Moffat and Gattis have made $21^{\text {st }}$ century London a central character in their adaptation of Sherlock Holmes, one that unsettles the mind and undisputedly demonstrates that it is always "time to be Sherlock Holmes." (The Great Game) 


\section{Conclusions}

In 1989, the Spanish sociologist Manuel Castells heralded "a technological revolution of historic proportions in transforming the fundamental dimensions of human life: time and space." (p. 1) Pre-dating the Internet upsurge and the globalization of communication practices of the $21^{\text {st }}$ century, Castells' 'informational city' has brought the architecture of the urban space to a new level. "The new spatial logic, characteristic of the Informational City, is determined by the preeminence of the space of flows over the space of places." (1996, p. 136) In other words, the geography/morphology of urban space has changed to accommodate a new reality: that of the digitized metropolis, of the globalized cyberspace in which information 'flows' unhindered by spatial borders. One of the consequences of the new millennial spatial development is the anomic and alienating effect it has on human beings. Paradoxically, despite the fast communication technology and the networks of social interaction, people experience a feeling of estrangement leading to a loss of control and meaning in their lives.

Moreover, the accelerated rhythm of the $21^{\text {st }}$ century metropolis generates sensorial overstimulation and cognitive overload which can only be addressed through 'civil inattention' and a 'proper' amount of indifference to others. Goffman's subtle observation of a behavioral pattern which regulates social life in urbanized mass societies brings into focus the existence of a new spatial dimension: the non-places or the transitory places where human actors pass through as anonymous individuals. Such places are defined by what they lack: relationship, intimacy, bonding, familiarity. These are places where the encounter with the other is neither mediated by proximity nor validated by it. Physical closeness in space does not necessarily mean togetherness or rapport. It only enhances the feeling of alienation by depersonalizing relationships.

In the context of all these challenges, the new millennial Sherlock has adapted his 'ways', both societal and reasoning, to ensure he can still function as a consulting detective. A highly unsocial, impulsive, pathologically manipulative one yet digitally astute and brilliantly insightful. $21^{\text {st }}$ century Sherlock is ultimately the product of all the attributes of metropolitan hyperstimulation, social distancing and fast-travelling information. In an age of digital amassing of knowledge, no brain stimulating 'warm-up' or ancient mnemonic technique can ever successfully substitute an electronically enhanced database. And yet, Sherlock does not fall prey to the enticements of the seductive internet-based 'sirens'. Though his battle is still with modern 'sphinxes' and plaguing 'gods', Sherlock knows that digitized information is only instrumental to his detective 'exploits'. He has remained fully organic and utterly human. A hubristic character, an Oedipal detective, the post-modern version of a tragic hero.

\section{References}

Adler, F. and Laufer, W. S. (Eds.). (2000). The Legacy of Anomie Theory, New Brunswick, New Jersey: The State University.

Castells, M. (1989). The informational city: Information technology, economic restructuring, and the urban-regional process, Oxford: Basil Blackwell.

Castells, M. (1996). The Rise of the Network Society, The Information Age: Economy, Society and Culture, vol. I, Oxford: Blackwell. 


\section{iorhs}

4th International Conference On Research In HUMANITIES \& SOCIAL SCIENCES

De Meyer, D. and Versluys, K. (1999). The Urban Condition: Space, Community and Self in the Contemporary Metropolis, the Ghent Urban Studies Team, Rotterdam: 010 Publishers.

Durkheim, E. (1952). Suicide. A Study in Sociology. Routledge \& Kegan Paul.

Fyfe, P. (2015). Accident or Design. Writing the Victorian Metropolis, Oxford University Press.

Goffman, E. (1966). Behaviour in Public Places. Notes on the Social Organization of Gatherings, New York: The Free Press.

Harraway, D. (1991). Simians, Cyborgs and Women: The Reinvention of Nature, New York: Routledge.

Laughlin, J. (2000). Writing the Urban Jungle: Reading Empire in London from Doyle to Eliot. The University Press of Virginia.

Lee C. (2014). "Welcome to London. Spectral Spaces in Sherlock Holmes's Metropolis". Cultural Studies Review, 20(2), pp. 172-195.

Longhurst, B., Smith G., Bagnall, G., Crawford, G., \& Ogborn, M. (2013). Introducing Cultural Studies, $2^{\text {nd }}$ ed., New York: Routledge.

Pleßke, N. (2014). The Intelligible Metropolis. Urban Mentality in Contemporary London Novels. Bielefeld: Transcript Verlag.

Porter, L. (Ed.). (2012). Sherlock Holmes for the $21^{\text {st }}$ Century. Essays on New Adaptations, Jefferson, North Carolina and London: McFarland \& Company, Inc., Publishers.

Redmond, C. (1993). Sherlock Holmes Handbook, Louiseville: Simon \& Pierre Publishing Co. Ltd.

Scaggs, J. (2005). Crime Fiction. The New Critical Idiom. London and New York: Routledge.

Stein, L. and Busse, K. (Eds.). (2012). 'Sherlock' and Transmedia Fandom. Jefferson, North Carolina and London: McFarland \& Company, Inc., Publishers.

Vanacker, S. and Wynne, C. (Eds.). (2013). Sherlock Holmes and Conan Doyle. Multi-media afterlives, Palgrave Macmillan.

Werner, A. (Ed.). (2014). Sherlock Holmes. The Man Who Never Lived and Will Never Die. London: Ebury Press.

Yochelson, S. and Samenow, S. (2004). The Criminal Personality: A Profile for Change, Oxford: Rowman and Littlefield Publishers. 